УДК 342.4

DOI https: / / doi.org/10.32837/yuv.v0i1.2078

\title{
О. Колодій,
}

кандидат юридичних наук,

старший викладач кафедри теорії держави та права

Національної академії внутрішніх справ

\section{СУТНІСТЬ КОНСТИТУЦІЙНО-ПРАВОВОГО СТАТУСУ УКРАЇНСЬКОГО НАРОДУ}

Постановка проблеми. Беззаперечно, що з'ясування сутності конституційно-правового статусу Українського народу треба розпочати із дослідження категорій «суть», «сутність», «суттєвий», а також дослідити ті правові категорії цього ж понятійно-категоріального ряду, які тісно взаємопов'язані із сутністю конституційно-правового статусу Українського народу.

Метою статті $€$ розкриття сутності конституційно-правового статусу Українського народу.

Виклад основного матеріалу. «Новий тлумачний словник української мови» передбачає, що «СУТНІСТЬ, ності, ж. 1. Найголовніше, основне, істотне в кому-, чому-небудь; суть, зміст. 2. У філософії - головне, визначальне в предметі, що зумовлене глибинними зв'язками й тенденціями розвитку і пізнається на рівні теоретичного мислення» [1, с. 485]. «Великий тлумачний словник сучасної української мови» додає до цього, що «СУТТЕВИЙ, -а, -е. Який становить саму суть, зміст чого-небудь; важливий, значний / / у знач. ім. суттєве, -вого, с. Те, що становить саму суть, зміст чого-небудь. // Який має велике, особливе значення» [2, с. 1218]. 3 огляду на вищевикладене $є$ всі підстави стверджувати, що сутність $€$ філософським поняттям, яке можна застосовувати для пізнавальної діяльності різних соціальних якостей розвитку та функціонування людства, суспільства, держави, права, у тому числі й конституційно-правового статусу Українського народу.

Можна також стверджувати, що поняття «сутність» являє собою глибинні, найбільш істотні особливості, які $€$ не формальними, а змістовими і вимагають глибокого осмислення. «Сутність (есенція) - філософська категорія, що виражає головне, основне, визначальне в предметі, таке, що зумовлене глибинними, необхідними, внутрішніми зв'язками й тенденціями розвитку і пізнається на рівні теоретичного мислення» [3]. Застосовуючи категорію «сутність» до юридичних явищ, треба врахувати, що, «оскільки «сутність» означає сукупність найбільш глибоких, стійких якостей предмета (у такому разі права), що визначають його походження, характер і напрями розвитку, предметом дискусії були причини виникнення права, його визначення, роль у суспільстві, якісні ознаки тощо. Для одних суб'єктів право - це інструмент справедливості і свободи, засіб захисту людини від влади, надбання людської культури і розуму, для інших - лише класовий регулятор суспільних відносин» [4, с. 286].

Iз вищезазначеного стає зрозумілим, що сутність демонструє найголовніші, найвизначніші характеристики та якості певного предмета, у такому разі конституційно-правового статусу Українського народу. Вона демонструє, що являє собою такий предмет, його походження, буття, функціонування, перспективи 


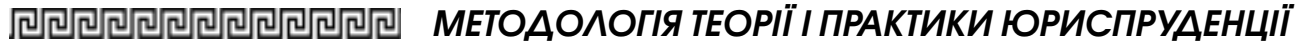

розвитку, місце і роль у житті суспільства, держави, особи. Тобто сутність як соціально-цілісна система включає у себе певні різні взаємопов'язані ознаки та елементи предмета, що і становлять його внутрішню сторону.

Отже, «сутність права - це внутрішній зміст права як регулятора суспільних відносин, який виражається в єдності загальносоціальних і вузькокласових (групових) інтересів через формальне (державне) закріплення міри свободи, рівності та справедливості» [5]. Водночас «сутність права вбачається в тому, що воно $€$ соціальним регулятором, особливою мірою свободи, грунтується на надбаннях розвитку людської цивілізації і культури, виступає критерієм визначення суспільної корисності чи небезпечності поведінки людей та їх об'єднань» [6, с. 160].

Грунтуючись на викладеному, можна також стверджувати, що сутність конституційно-правового статусу Українського народу різноаспектна, а тому вимагає використання комплексних форм і методів ii пізнання. $€$ сенс також визнати, що на розуміння сутності конституційно-правового статусу Українського народу впливають також історичні та політичні обставини, у яких вона осмислюється, домінуюча правова доктрина, політичний режим та форма правління, які панують у державі i навіть мета та завдання наукового дослідження тощо.

Таким чином, вищезазначене дає нам усі підстави стверджувати, що сутністю конституційно-правового статусу Українського народу $€$ визнання його повноцінним суб'єктом усіх (політичних, економічних, правових, духовних та інших) суспільних відносин, що мають місце у соціальному житті, гарантування його системоутворюючого права бути носієм суверенітету, єдиним джерелом влади, здійснювати владу безпосередньо і через органи державної влади та органи місцевого самовряду- вання, визначати і змінювати конституційний лад в Україні, утворювати власне суспільство, державу, право, контролювати та змінювати їх.

Беручи до уваги вищевикладене та співвідносячи між собою зміст категорій «суть», «сутність», «суттєвий», можна дійти висновку, що найбільш оптимальним буде дослідження сутності конституційно-правового статусу Українського народу через аналіз його функцій, адже в юридичній науці термін «функції використовується для позначення сутності, соціального призначення, соціальної ролі того чи іншого правового явища в суспільстві, державі, праві тощо. У цьому контексті вчені стверджують, що категорія «функції держави» тісно пов'язана з такими поняттями, як «сутність» та «діяльність держави». Л. Каск зазначав, що шлях до пізнання сутності держави лежить насамперед через пізнання іï функцій. На думку I. Ільїнського, тільки сутність держави може надавати їі функціям відповідної соціально-політичної та морально-цілісної визначеності, яка, своєю чергою, проєктується на практичну діяльність» [7, с. 99].

До того ж учені констатують, що «функції права - це основні напрями юридичної дії права на наявні суспільні відносини, що реально визначають сутність і соціальне призначення права в житті суспільства» [8, с. 167]. Таким чином, можна стверджувати, що дослідження функцій конституційно-правового статусу Українського народу $€$ запорукою пізнання головного і визначального в його середовищі, виявлення його соціального змісту, призначення, порівняння 3 іншими соціальними явищами, дослідження його сутності. 3 огляду на це є всі підстави дійти висновку, що сутність конституційно-правового статусу Українського народу - це насамперед головні напрями реалізації його соціального призначення, тобто функції конституційно-правового статусу Українського народу. 
Але для забезпечення повноцінності та об'єктивності такого розгляду доцільно проаналізувати наявні доктринальні точки зору на функції правового, конституційно-правового статусу Українського народу, суспільства, держави та інших близьких за сутністю соціальних інститутів.

Так, Л. Шипілов вважає, що «систему функцій народовладдя в Україні становлять: установча (державна та конституційна); уповноважуюча (вибори та призначення), державно-організаційна (здійснюється безпосередньо народом та його представницькими інститутами) та контрольна (громадська, парламентська, президентська, конституційна), які відображають головні сторони здійснення влади народу» [9, с. 16].

В іншій своїй роботі він стверджує, що «можна визначити чотири основні функції здійснення народовладдя: установчу, уповноваження, контрольну та державно-організаційну. Наведені функції являють головні сторони здійснення влади народом: іï встановлення, уповноваження конкретних осіб шляхом виборів чи призначення, здійснення влади та контроль за іiі здійсненням. Усі зазначені функції можуть здійснюватися як у безпосередній, так і представницькій формах народовладдя» [10, c. 147].

Разом із тим треба визнати, що у дисертаційному дослідженні та монографії «Народовладдя як основа демократичної держави» Л. Шипілова йдеться про функції народовладдя в Україні, тобто тільки функції здійснення влади народом України, а предметом статті $є$ функції конституційно-правового статусу Українського народу, що $є$ набагато більш широким предметом осмислення, оскільки необхідно вести мову про функції правового становища Українського народу у власному суспільстві, державі, регіональних та міжнародних спільнотах. Цим, власне кажучи, і пояснюються відмін- ності у розумінні та виокремленні цих двох груп функцій.

M. Дзевелюк, осмислюючи традиції та новації в розвитку функцій сучасної держави, надзвичайно цікаво пропонує «розглядати функції держави як особливі канали комунікації між державою і суспільством, що виникають унаслідок раціоналізаціі їх нормативних та інституційних засад, що веде до їх становлення як дискурсів - стабільних і тривалих форм взаємодії між людьми, покликаних вирішувати завдання загальносуспільного значення». Акцентує на доцільності виокремлення явних і латентних, мінімальних та додаткових функцій сучасної держави [11, с. 3].

В. Сало досліджує внутрішні функціі держави в умовах членства в Європейському Союзі. Він визнає функції держави основними соціально значущими напрямами іiі діяльності; характеризує їх як стійку предметну діяльність, без якої держава не може обійтися протягом усього або такого етапу існування; стверджує зумовленість функцій завданнями і цілями, що дозволяє виділити таку ï ознаку, як об'єктивний характер; доводить, що реалізація функцій держави здійснюється притаманними їй методами і формами; наголошує на ї системному характері. Окрім цього зазначається, що «найбільш важливим і вихідним у процесі класифікації $є$ поділ функцій за сферами суспільного життя на політичну, економічну, соціальну, екологічну та інші функції, а також похідний від нього поділ на внутрішні та зовнішні функції залежно від сфери політичної діяльності» $[12$, с. 7$]$.

M. Булкат, здійснюючи теоретикоправовий аналіз зовнішніх функцій України, стверджує, що «зовнішня функція держави - це сукупність напрямів зовнішньої діяльності держави у певній галузі, що формується відповідно до іiі завдання, відповідає змісту, призначенню, ролі та місцю держави у суспільстві та світі, 


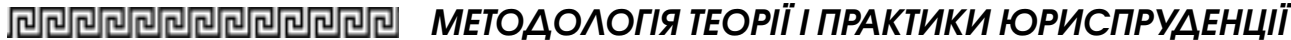

реалізується у притаманних їй формах і відповідними методами». Вона виокремлює зовнішньоекономічну, зовнішньополітичну, зовнішньогуманітарну, зовнішньоекологічну, зовнішньозахисну функції України [13, с. 6]. Звертає на себе увагу те, що автор фактично ототожнює зовнішні функції України і зовнішні функції держави Україна, але зазначене виокремлення функцій Украіни має право на існування.

А. Панчишин угруповує функції правового статусу держави за такими критеріями: «відповідно до основних сфер суспільного життя (загальносоціальні, політичні, економічні); територіальними факторами (внутрішні, зовнішні, комплексні); сутністю та призначенням держави (соціальні, національні) [14, с. 5]. 3 приводу цього можна зазначити, що не викликає сумнівів той факт, що необхідно розрізняти функції конституційноправового статусу Українського народу та функції правового статусу держави, але сам підхід А. Панчишина до виокремлення функцій правового статусу держави видається надзвичайно цікавим.

В. Шатіло, досліджуючи конституційний механізм державної влади в Україні визначає його функції «як напрями діяльності суб'єктів конституційного механізму державної влади в межах компетенції, визначеної в Конституції та законах України, що спрямовані на досягнення цілей і завдань держави». Класифікує їх за різними критеріями, а саме: «за сферами діяльності суб'єктів конституційного механізму державної влади: а) внутрішні (соціальна, економічна, політична, культурна, виховна, екологічна, бюджетно-фінансова та ін.); б) зовнішні (зовнішньополітична, зовнішньоекономічна, оборонна та ін.); в) за принципом поділу державної влади (законодавча, виконавча, судова); г) за змістом діяльності суб'єктів конституційного механізму державної влади (правозахисна; правоохоронна; правозабезпечувальна; правозастосовна; нормотворча; регулятивна; організаційна (організаційно-управлінська, державно-владна)); контрольна (контрольно-наглядова); інформаційна» [15, с. 15].

I. Мотиль характеризує процес становлення та розвитку внутрішніх функцій української держави як основний напрям державної діяльності відповідно до потреб демократизаціï суспільного життя, захисту прав і свобод людини і громадянина, забезпечення принципів соціальної справедливості [16, с. 4].

В. Кафарський, класифікуючи функції політичних партій за законодавством України виділяє функції «політичні, соціалізації, формування громадської думки, статутні (внутрішньопартійні) та виховні, функції контролю та критики, доведено, що функції політичних партій переплітаються 3 основними функціями політичної системи суспільства» $[17$, с. 5].

Висновки. Лише 3 урахуванням усього вищевикладеного є всі підстави виділити функції конституційно-правового статусу Українського народу. При цьому одразу ж хотілося б наголосити, що у сучасних інтерпретаціях функцій їх здебільшого розглядають як напрям діяльності. Проте хотілося б зазначити, що не всякий напрям діяльності Українського народу можна визнати його функцією, а тільки найбільш важливий із них, той, який демонструє його сутність і соціальне призначення. I навіть за такого підходу не забезпечується абсолютна рівнозначність функцій за своєю вагомістю й значущістю для Українського народу. Саме тому і можна вести мову про основні та неосновні функції Українського народу.

У иій науковій статmі розкрито сутність конституиійно-правового статусу Українського народу.

Визначено, що сутність демонструе найголовніші, найвизначніші характеристики та якості певного предмета, у цьому разі 
конституційно-правового статусу Українського народу. Вона демонструе, що являе собою такий предмет, його походження, буття, функијонування, перспективи розвитку, місце $і$ роль у житті суспільства, держави, особи. Тобто сутність як соціально-цілісна система включає у себе певні різні взаємопов'язані ознаки та елементи предмета, що і становлять його внутрішню сторону.

Наголошено, що сутністю конституційно-правового статусу Українського народу є визнання його повноцінним суб'єктом всіх (політичних, економічних, правових, духовних ma інших) суспільних відносин, щзо мають місиее $y$ соціальному житті, гарантування його системоутворюючого права бути носієм суверенітету, єдиним джерелом влади, здійснювати владу безпосередньо $і$ через органи державної влади та органи місцевого самоврядування, визначати $i$ змінювати конституційний лад в Україні, утворювати власне суспільство, державу, право, контролювати та змінювати ї.

Акиентовано увагу, шо необхідність визнання принципів елементами конституційно-правового статусу Українського народу зумовлюеться тим, що саме вони спільно із функціями демонструють сутність, соціальне призначення та соціальну цінність конституційно-правового статусу Українського народу.

Наголошено, шо у сучасних інтерпретаціях функциій їх здебільшого розглядають як напрям діяльності. Проте хотілося б зазначити, що не всякий напрям діяльності Українського народу можна визнати його функцією, а тільки найбільш важливий із них, той, який демонструє його сутність $i$ сойіальне призначення. I навіть за такого підходу не забезпечуеться абсолютна рівнозначність функиій за своєю вагомістю й значущістю для Українського народу. Саме тому $і$ можна вести мову про основні та неосновні функції Українського народу.

Ключові слова: Український народ, правосуб'єктність, гарантії конституційних прав, права та обов'язки, конституційно-правовий статус Украінського народу.

Kolodii O. Essence of the constitutional and legal status of the Ukrainian people

This scientific article reveals the essence of the constitutional and legal status of the Ukrainian people. It is determined that the essence demonstrates the most important, most significant characteristics and qualities of a certain subject, in this case the constitutional and legal status of the Ukrainian people. It demonstrates what is a given object, its origin, existence, functioning, prospects for development, place and role in society, state, person.

That is, the essence as a socially holistic system includes certain various interconnected features and elements of the object, which constitute its inner side. It is emphasized that the essence of the constitutional and legal status of the Ukrainian people is the recognition of its full-fledged subject of all (political, economic, legal, spiritual and other) social relations that take place in social life, guaranteeing its system-forming right to be the bearer of sovereignty. To exercise power directly and through state authorities and local governments, to determine and change the constitutional order in Ukraine, to form their own society, state, law, to control and change them.

Emphasis is placed on the need to recognize the principles as elements of the constitutional and legal status of the Ukrainian people due to the fact that they, together with the functions, demonstrate the essence, social purpose and social value of the constitutional and legal status of the Ukrainian people. It is emphasized that in modern interpretations of functions they are mostly considered as a direction of activity. 


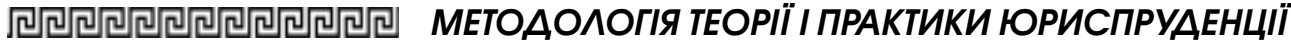

However, I would like to stipulate that not every direction of activity of the Ukrainian people can be recognized as its function, but only the most important of them, the one that demonstrates its essence and social purpose. And even with such an approach, the absolute equivalence of functions in terms of their weight and significance for the Ukrainian people is not ensured. That is why we can talk about the basic and non-basic functions of the Ukrainian people.

Key words: Ukrainian people, legal personality, guarantees of constitutional rights, rights and responsibilities, constitutional and legal status of the Ukrainian people.

\section{Література}

1. Новий тлумачний словник української мови: у 3 m. Київ : Аконіт, 2003. T. 3. 2003. 928 c.

2. Великий тлумачний словник сучасної української мови / уклад. і голов. ред. В.Т. Бусел. Київ; Ірпінь : ВТФ «Перун», 2002. 1440 c.

3. Вікіпедія - вільна енииклопедія. Cymнicmb. URL: http: / / uk.wikipedia.org / wiki / Cymнicmb.

4. Теорія держави і права. Академічний курс : підручник / за ред. О.В. Зайчука, H.М. Оніщенко. Київ : Юрінком Інтер, 2006. 688 c

5. Скакун О.Ф. Теорія держави $і$ права : підручник / пер. 3 рос. Харків : Консум, 2001. 656 c. URL: http:// politics.ellib.org.ua/pages-1626.html.

6. Теорія держави і права : підручник / С.Л. Лисенков, А.М. Колодій, О.Д. Тихомиров, В.С. Ковальський ; за ред. С.Л. Лисенкова. Київ : Юрінком Iнmep, 2005. $448 \mathrm{C}$.

7. Теорія держави $і$ права : навчальний посібник / С.К. Бостан, С.Д. Гусарев, H.M. Пархоменко та ін. Київ : ВЦ «Академія», 2013. 348 с.

8. Коталейчук С.П. Теорія держави та права в запитаннях $i$ відповідях : навчальний посібник для студентів вищих навчальних закладів / С.П. Коталейчук, П.Я. Пісной. Київ : КНТ, 2011. 560 c.
9. Шапілов Л.М. Принции народовладдя $i$ його здійснення в Україні : автореф. дис. ... канд. юрид. наук : 12.00 .01 «Теорія та історія держави $i$ права; історія політичних і правових учень» Харків, 2004. 19 с.

10. Шипілов Л.М. Народовладдя як основа демократичної держави : монографія. Харків : Видавництво «ФІНН», 2009. 216 c

11. Дзевелюк М.В. Традииії та новації в розвитку функцій сучасної держави : автореф. дис. ... канд. юрид. наук : 12.00 .01 «Теорія та історія держави $i$ права; історія політичних $i$ правових учень». Одеса, 2017. 20 с.

12. Сало B.I. Внутрішні функиії держави в умовах иленства в Европейському Союзі : автореф. дис. ... канд. юрид. наук : 12.00 .01 «Теорія та історія держави і права; історія політичних і правових учень». Харків, 2008. 20 с.

13. Булкат M.C. Зовнішні функції України (теоретико-правовий аналіз) : автореф. дис. ... канд. юрид. наук : 12.00 .01 «Теорія та історія держави і права; історія політичних $i$ правових учень». Київ, 2013. 20 c.

14. Панчишин А.В. Правовий статус держави: теоретико-правовий аспект : автореф. дис. ... канд. юрид. наук : 12.00 .01 «Теорія та історія держави і права; історія політичних $і$ правових учень». Київ, 2014. 20 c.

15. Шатіло В.А. Конституційний механізм державної влади в Україні: проблеми співвідношення організаційних структур $i$ функцій : автореф. дис. ... докт. юрид. наук : 12.00.02 «Конституційне право; муніципальне право». Київ, 2018. 35 с.

16. Мотиль I.I. Становлення та розвиток внутрішніх функцій української держави : автореф. дис. ... канд. юрид. наук : 12.00 .01 «Теорія та історія держави і права; історія політичних $і$ правових учень». Київ, 2007. 20 с.

17. Кафарський B.I. Конституціийно-правове регулювання організації та діяльності політичних партій в Україні : автореф. дис. на здобуття наук. ступеня доктора юрид. наук : 12.00 .02 «Конституиійне право; муніципальне право». Киї, 2010. 36 c. 